\title{
Impact of damming on the Chironomidae of the upper zone of a tropical run-of-the-river reservoir
}

\author{
A. L. Brandimarte ${ }^{*}$, M. Anaya ${ }^{b}$ and G. Y. Shimizu ${ }^{a}$ \\ ${ }^{a}$ Departamento de Ecologia, Instituto de Biociências, Universidade de São Paulo - USP, Rua do Matão, \\ Travessa 14, CP 321, CEP 05508-900, Cidade Universitária, São Paulo, SP, Brazil \\ bUniversidade Cidade de São Paulo - UNICID, Rua Cesário Galeno, 448/475, \\ CEP 03071-000, Tatuapé, São Paulo, SP, Brazil \\ *e-mail: anabrand@ib.usp.br
}

Received: August 15, 2014 - Accepted: February 9, 2015 - Distributed: May 31, 2016

(With 7 figures)

\begin{abstract}
We examined the effects of the Mogi-Guaçu river damming (São Paulo State, Brazil) on the Chironomidae fauna. Pre, during, and post-filling sampling was carried out in the main channel and margins of one site in the upper zone of the reservoir, using a modified Petersen grab $\left(325 \mathrm{~cm}^{2}\right)$. We evaluated the total, subfamily, and tribe densities and also their relative abundance. Analysis of genera included densities, relative abundance, richness, and dominance. The Rosso's ecological value index $(E V I)$ determined the ecological importance of each genus. There was a tendency of decrease of the total Chironomidae density, increase in the percentage of Chironomini, and decrease in densities and percentages of Orthocladiinae and Tanytarsini. These changes in percentage were respectively related to Polypedilum, Lopescladius, and Rheotanytarsus, the genera with the highest EVI values. After-filling richness was lower in the margins and dominance of genera did not change significantly. Chironomidae in the margins was more sensitive to damming than in the main channel. This difference in sensibility sustains the use of Chironomidae as bioindicators. Damming impact was indicated by the reduction of both genera richness in the margins and relative abundance of groups typical of faster waters. The results have highlighted the need for multi-habitat analysis combined with a before-after sampling approach in the environmental impact studies concerning the damming impact on the benthic fauna.
\end{abstract}

Keywords: bioindicators, taxocenose composition and structure, before after sampling design.

\section{Impacto de um represamento sobre Chironomidae do remanso de um reservatório fio d'água tropical}

\section{Resumo}

Este trabalho teve como objetivo avaliar o impacto do represamento do Rio Mogi-Guaçu, em um ponto situado na zona de remanso do reservatório, através da utilização da taxocenose Chironomidae. A amostragem foi realizada antes, durante e após o represamento, no canal e nas margens, com o auxílio de um pegador Petersen modificado (área de $325 \mathrm{~cm}^{2}$ ). Calculou-se a densidade total, de subfamílias, tribos e gêneros de Chironomidae, bem como sua abundância relativa. Estimou-se a riqueza e a dominância de gêneros. O índice de valor ecológico de Rosso (IVE) foi utilizado para avaliar a importância ecológica dos diferentes gêneros. Houve tendência de redução da densidade total de Chironomidae, aumento da abundância relativa de Chironomini e diminuição das abundâncias relativas de Orthocladiinae e Tanytarsini. Estas alterações de abundância relativa foram relacionadas respectivamente a Polypedilum, Lopescladius e Rheotanytarsus, gêneros que apresentaram os maiores valores de IVE. Após o represamento, houve decréscimo da riqueza de gêneros na margem, enquanto a dominância não apresentou alteração significativa. A taxocenose de Chironomidae das margens mostrou-se mais sensível ao represamento que a do canal. Esta diferença de sensibilidade confirma o potencial dos Chironomidae como bioindicadores. A ocorrência de impacto foi observada através da diminuição da riqueza de gêneros nas margens e da abundância relativa de táxons característicos de águas mais rápidas. Os resultados chamam atenção para a necessidade de utilizar a abordagem de múltiplos habitats combinada com a amostragem antes e depois do evento na avaliação dos impactos causados por represamento sobre a fauna bentônica.

Palavras-chave: bioindicadores, composição e estrutura da taxocenose, amostragem pré e pós-impacto. 


\section{Introduction}

Chironomidae larvae are among the major components of benthic communities in most freshwater ecosystems, where they can reach high densities and richness (Oliver, 1971; Pinder, 1986; Cranston, 1995). Impacts on aquatic ecosystems can be followed by shifts in the Chironomidae that have been used in biomonitoring and environmental impact assessments, from organisms to the community level (Rosenberg et al., 1986). In general, the effects of dam construction on Chironomidae are evaluated by comparing sites located upstream and downstream the reservoir and the taxonomic identification varies from family (Nichols et al., 2006) to species (Penczak et al., 2006; Glowacki et al., 2010; Grzybkowska et al., 2012) and morphospecies (Rosin et al., 2009). In some cases, authors also analyse data using tribe and subfamily level (e.g. Grzybkowska et al., 2012).

For decades, knowledge of the conditions prior to damming has been considered fundamental to the assessment of dam impacts, as many rivers have been fragmented without prior knowledge of the of the lost species' ecological role (Petr, 1978; Petts, 1984; Power et al., 1988). However, comparing fauna of the same site in pre- and post-reservoir construction seems to have been the exception in the reservoir impact evaluation in recent years. Penczak et al. (2006) analyzed Chironomidae assemblages before and after a hydroelectric plant began operating, but sampling began two years after reservoir construction.

Differences in reservoir operation, drowned areas, substrates, and trophic states make the responses of Chironomidae composition and metrics vary from one reservoir to another. Therefore, the statement of expected responses is not easy. It is particularly true to backwater sites because the bulk of the papers in reservoir impact focused on changes in the fauna of downstream sites by the comparison with sites located upstream the reservoir.

Previous studies carried out in the pre-filling and in the first-year post-filling of the Mogi-Guaçu reservoir damming revealed Chironomidae as the major component of the benthic fauna nearly all the sampling time. This result justifies a more detailed study about this family. These studies also showed low impact over the composition the communities of the main river channel upstream the reservoir and in the central zone of it. Moreover, similar temporal tendencies occurred for variation of richness of major taxonomic groups and Chironomidae genera (Brandimarte et al., 1997, 1999). This work aimed to use Chironomidae of the upper zone of the reservoir identified to levels behind family as a tool for evaluating the impact of the river damming. Based in the results quoted formerly, we hypothesized that the damming would not severely impact the larvae identified in levels behind family.

\section{Material and Methods}

\subsection{The study area}

The Mogi-Guaçu river has its origin in the Mantiqueira mountain range, Minas Gerais State, southeast Brazil (26 $16^{\prime}$ ' S, $46^{\circ} 42^{\prime} \mathrm{W}$; 1,650 m a.s.1.). It reaches Pardo River at São Paulo State after $473 \mathrm{~km}$ (377.5 km of which are in São Paulo State) and at about $490 \mathrm{~m}$ a.s.l. (Maier et al., 1978). The area is under the influence of the Köppen Cwa climate type - mesothermal with a dry winter, from June to September (CESP, 1993). The catchment has 17,560 km² and embodies 44 cities (37 in the São Paulo State); many of them unload raw sewage and wastewaters into the river. Significant industrial load is mostly released as effluents in the Mogi-Guaçu tributaries (CESP, 1993). The original vegetation was mainly semi-deciduos latifoliate tropical forest as well some "Cerrado" (Brazilian savannah) remainders. Nowadays, small and sparse fragments remain (CESP, 1993), and sugar cane culture and pasture dominate the landscape of the study area.

A multipurpose run-of-the-river reservoir, with four gated spillways and power generation of $7.2 \mathrm{~kW}$, was created on the Mogi-Guaçu river (São Paulo State, Brazil), at 598.5 meters a.s.1. (Figure 1). Initially, in November 1995 , the lake was filled to the volume required for water supply. Filling for the generation of electric power occurred in December 1995. Morphometric characteristics of the reservoir include length of $8 \mathrm{~km}$, surface area of $5.73 \mathrm{~km}^{2}$, volume of 12.56 million $\mathrm{m}^{3}$, dam height of $13.5 \mathrm{~m}$, dam length of $170 \mathrm{~m}$, spillway level at $594.3 \mathrm{~m}$ a.s.1. (CESP, 1993), and calculated mean retention time of 74 hours.

\subsection{Surface flow and depth analysis}

The surface flow was estimated using a float (an orange) and measuring the time of its passage across a measured distance (Wetzel and Likens, 1991).

The test $U$ of Mann-Whitney (Zar, 1999) was applied to compare values of depth and flow between pre- and post-filling phases.

\subsection{Substrate characterization}

The composition of the substrate was visually characterized for each sampling unit during the sampling period. The following fractions were recognized: stones, sand, sludge, and organic matter. Gravel and larger components were grouped as stones. Fractions finer than sand, but not necessarily muddy, were grouped as sludge. The frequency of occurrence of each fraction in the sampling units was calculated. The effect of the damming on the different fractions was evaluated deducting the frequency in the pre-filling phase from the frequency in the post-filling phase. The positive variation of a fraction shows that a higher number of sampling units contained the fraction in the post-filling phase. Negative variation indicates that a smaller number of sampling units contained the fraction in the post-filling phase.

\subsection{Sampling and fauna analyses}

The choice of reference sampling sites was difficult due to the hard access and navigability and the heavy influence of human activities in the study area. We applied an "impact inferred from temporal change alone" design sensu Green (1979) in order to compare the conditions before and after impoundment. One sampling site was established in the upper zone (backwater) of the reservoir (Figure 1) 


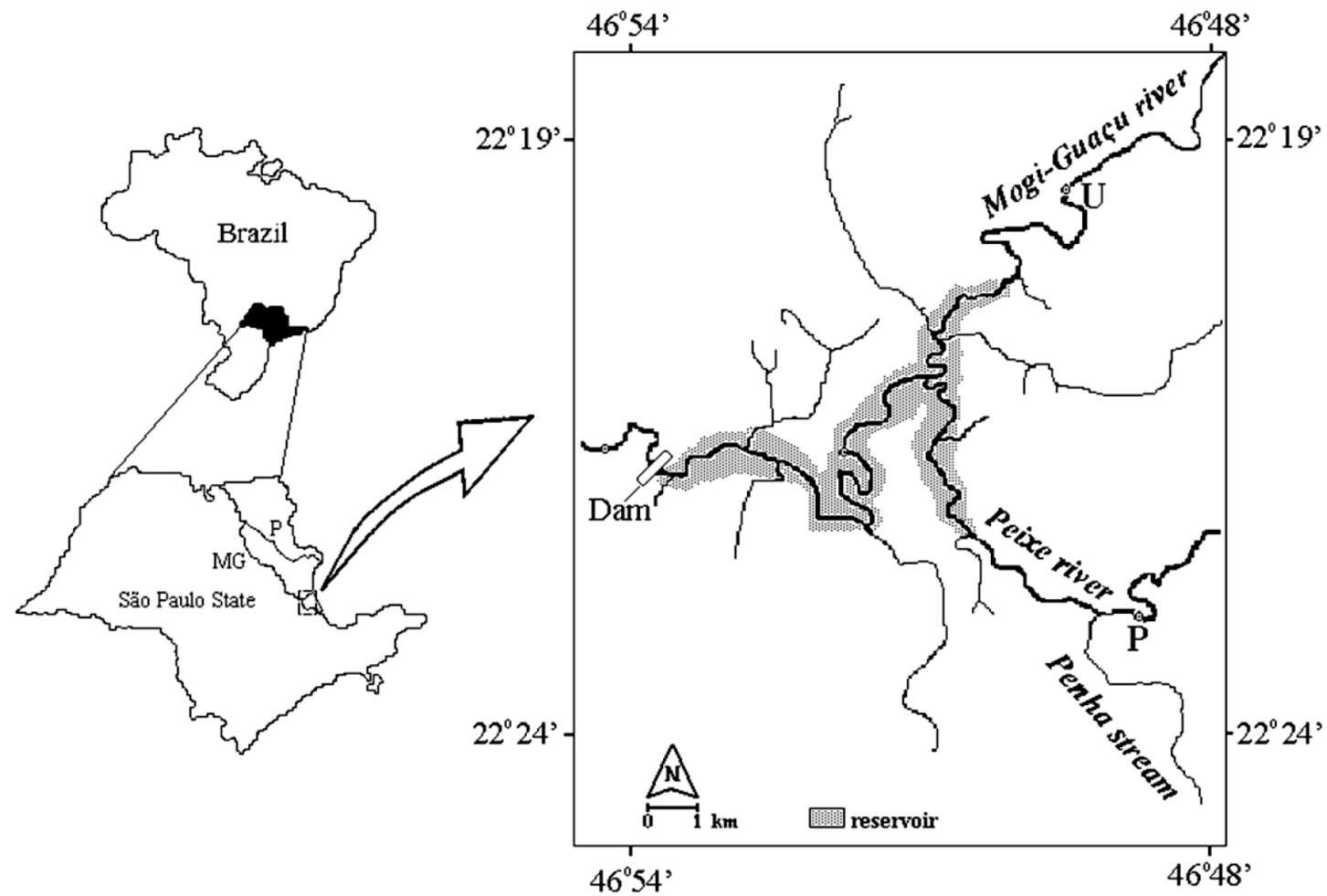

Figure 1. Mogi-Guaçu river with reservoir and sampling site location (U) (São Paulo State, Brazil). (MG: Mogi-Guaçu River; P: Pardo River).

in a straight stretch of the river. Substrate sampling was conducted from February 94 to August 94 before the river damming (Pre-Filling Phase), in November 95 during the initial filling (Filling), and trimestrially from February 96 to August 96 (Post-Filling Phase).

Using a simple random scheme, three sampling units of substrate were taken in the main channel (MC) and in the right (RM) and left (LM) margins with a modified Petersen grab $\left(325 \mathrm{~cm}^{2}\right)$ in each sampling date. Stones and small boulders were individually washed for attached individual removal. Organisms in coarse substrates were floated out with saturated $\mathrm{NaCl}$ solution (Brandimarte and Anaya, 1998). They were selected by a $250 \mu \mathrm{m}$ mesh, preserved in $4 \%$ neutral formalin, and stained with phloxine-B.

Chironomidae larvae were identified to the genus level using the keys of Epler (1992), Oliver et al. (1978), Wiederholm (1983), Coffman and Ferrington Junior (1996), and Trivinho-Strixino and Strixino (1995).

The density per square meter and the percent abundance were calculated for the total of Chironomidae, subfamilies, tribes, and genera. The calculation of density involves a rule of three on the basis of the number of individuals collected in the sampler area. In spite of the density not being a reliable representation of numbers of individuals in a square meter due to that extrapolation, it is a good tool for comparing among data from different papers. For that, the authors chose to use it instead of raw data.
Genera richness was considered the simple sum of genera in the sampling units. The use of measures of richness assumes the richness decreases with impact occurrence. Dominance was measured by the higher value of percent abundance, and its use is based on the assumption that the number of individuals of tolerant taxa increases if an impact is negative.

The test $U$ of Mann-Whitney (Zar, 1999) was applied to compare the density, richness, and dominance values between the pre- and post-filling phases. The Spearman rank correlation coefficient $\left(r_{S}\right)$ (Zar, 1999) was applied to search for correlation between Chironomidae densities (using subfamilies, tribes, and more abundant genera data) and surface flow. Statistic analysis was performed using the free data analysis package Past (PAlaentological STastistics) (Hammer et al., 2001).

The Rosso's ecological value index (EVI) (Equation 1 that results from the Equations 2 to 4) for quantitative analyses was applied to determine the ecological importance of each genus in the pre- and post-filling phases. This index was first developed to qualitative analyses by Pinder and Rosso (1998). The quantitative form (Rosso, personal communication) ranked the genera based on a geometric average of three components: genus's presence in the totality of observations, equitability in the samples in which the genus was registered, and the genus's overall relative abundance: 


$$
E V I_{j}=\sqrt[3]{P_{j} J_{j} A_{j}}
$$

where:

$P_{j}=\frac{n_{j}}{N}$

$n_{j}=$ samples with " $"$ genera and $N=$ total number of sampling units or occurrence;

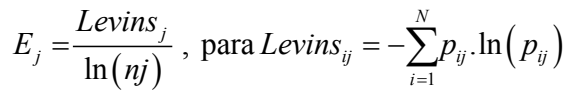

$E_{j}=$ the Levins measure of the niche breadth calculated with $p_{i j}$ (the relative abundance of genus “ $\mathrm{j}$ ” in the sample "i"); and

$$
A_{j}=\frac{\sum_{i=1_{i j}^{a}}^{N}}{\sum_{j=1}^{S} \sum_{i=1^{a} i j}^{N}}
$$

$a_{i j}=$ absolute abundance from genus " $\mathrm{j}$ " in the sample " $\mathrm{i}$ " (measuring the overall relative abundance).

The three components reach values between 0 and 1 , so the geometric average is also in this interval. Ecological values near 1 are related to genera with high frequency in the samples, high relative abundance, and high equitability. The difference between the EVI calculated for each sampling period was used as an impact measurement: a positive difference meant an increased ecological value for that genus in the post-filling phase; inversely, a negative difference meant a decreased ecological value in the same phase. The samples collected in November of 1995, during the filling phase, were removed from the calculation because they do not represent a well-defined (before or after) sample period.

\section{Results}

After the filling, the depth increased significantly in the margins and the main channel of the sampling site, and the surface flow decreased significantly, except for the left margin (Figure 2). The substrate also changed, mainly in the margins where it became finer (Figure 3 ).
The total density of Chironomidae tended to decrease after damming, and this reduction was significant in both of the margins (Figure 4). The density of Chironomidae was significantly correlated with surface flow: positive correlation for Orthocladiinae $\left(\mathrm{n}=27 ; r_{S}=0.4166 ; p=0.0306\right)$ and Lopescladius $\left(\mathrm{n}=27 ; r_{S}=-0.3901 ; p=0.015\right)$ and negative for Chironomini ( $\left.\mathrm{n}=27 ; r_{S}=-0.4893 ; p=0.0096\right)$.

The percent abundance tended to increase for Tanypodinae and Chironomini and decrease for Orthocladiinae and Tanytarsini (Figure 5). In relation to significant changes of densities, Tanypodinae increased significantly in the left margin, Orthocladiinae decreased in the main channel and margins, and Tanytarsini decreased in the right margin (Figura 4).

Lopescladius, Polypedilum, Parachironomus, and Rheotanytarsus had the highest densities and, with few exceptions, occurred during all the sampling period (Figure 6). Decreases of Orthocladiinae and Tanytarsini reflected respectively mainly the declines of Lopescladius that was significant in the right margin $(\mathrm{U}=17.5 ; p=0.0057)$ and main channel $(\mathrm{U}=33 ; p=0.0139)$ and Rheotanytarsus that was significant in the right margin $(\mathrm{U}=15.5 ; p=0.0056)$.

The Rosso's EVI decreased for Lopescladius and Polypedilum and increased for Parachironomus and Rheotanytarsus. The major differences in EVI between pre- and post-filling phases occurred for Lopescladius and Parachironomus (Table 1).

Table 1. Ecological value index for Chironomidae genera with Rosso's $E V I>0.20$ in pre and post-filling phases in the upper zone of Mogi-Guaçu reservoir (São Paulo State, Brazil).

\begin{tabular}{ccccc}
\hline \multirow{2}{*}{ Genus } & \multicolumn{4}{c}{ EVI } \\
\cline { 2 - 5 } & $\begin{array}{c}\text { Total } \\
\text { Period }\end{array}$ & $\begin{array}{c}\text { Pre- } \\
\text { Filling }\end{array}$ & $\begin{array}{c}\text { Post- } \\
\text { Filling }\end{array}$ & Difference \\
\hline Lopescladius & 0.50 & 0.46 & 0.24 & -0.22 \\
Polypedilum & 0.46 & 0.49 & 0.38 & -0.11 \\
Parachironomus & 0.35 & 0.24 & 0.44 & 0.20 \\
Rheotanytarsus & 0.33 & 0.41 & 0.49 & 0.08 \\
\hline
\end{tabular}
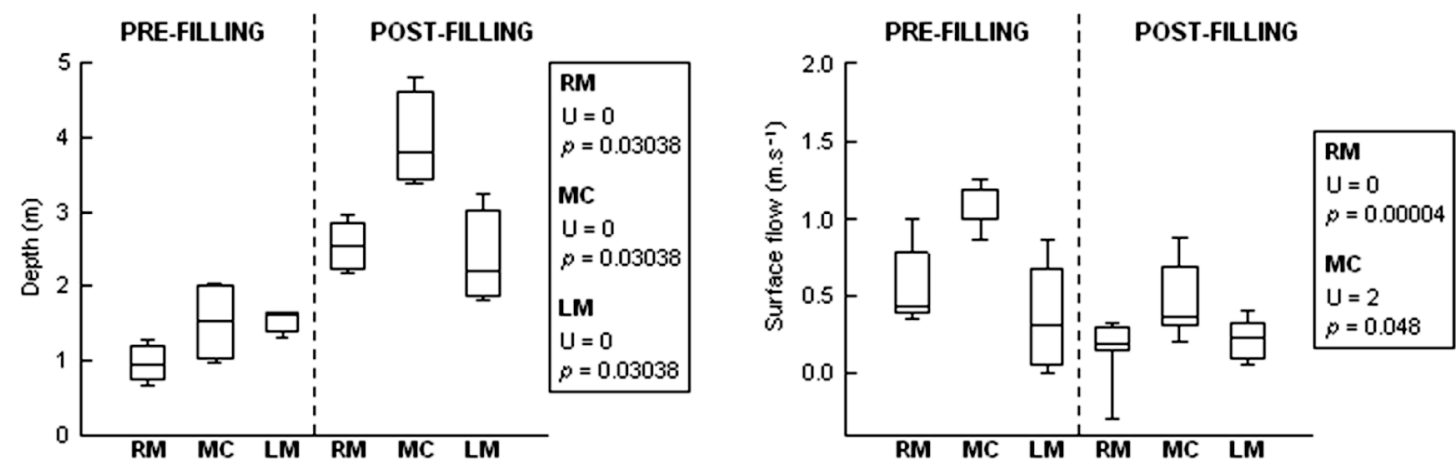

Figure 2. Median, percentiles, maximum, and minimum values of depth $(\mathrm{m})$, and surface flow $\left(\mathrm{m} . \mathrm{s}^{-1}\right)$ in pre- and post-filling phases in the right margin (RM), main channel (MC), and left margin (LM) in the upper zone of Mogi-Guaçu reservoir (São Paulo State, Brazil), showing significant results for the $U$ test. 


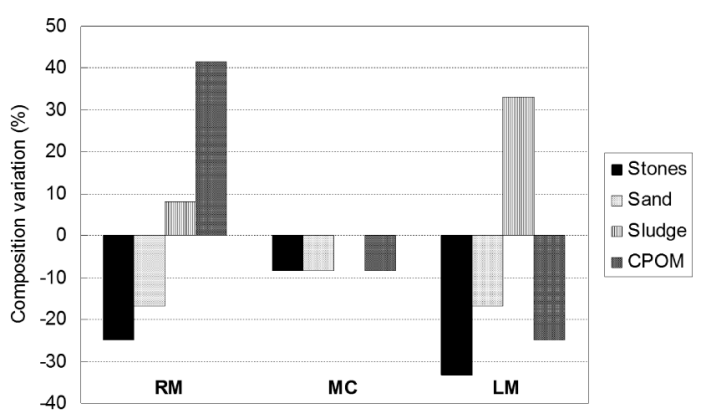

Figure 3. Substrate variation between pre-filling and post-filling phases in the right margin (RM), main channel (MC) and left margin (LM) in the upper zone of Mogi-Guaçu reservoir (São Paulo State, Brazil).
In the post-filling phase, the month values of dominance remained in the same range as the pre-filling phase, whereas richness was lower in the margins (Figure 7).

\section{Discussion}

Contrary to expectations, relevant changes occurred in the Chironomidae structure of the upper zone of the Mogi-Guaçu reservoir. The occurrence of impact was indicated by richness decrease in the margins and by a reduction in the relative abundance of taxa representative of faster waters. The fauna in the margins, mainly in the left one, was more sensitive to the damming than the fauna in the main channel was. This fact is related to changes in
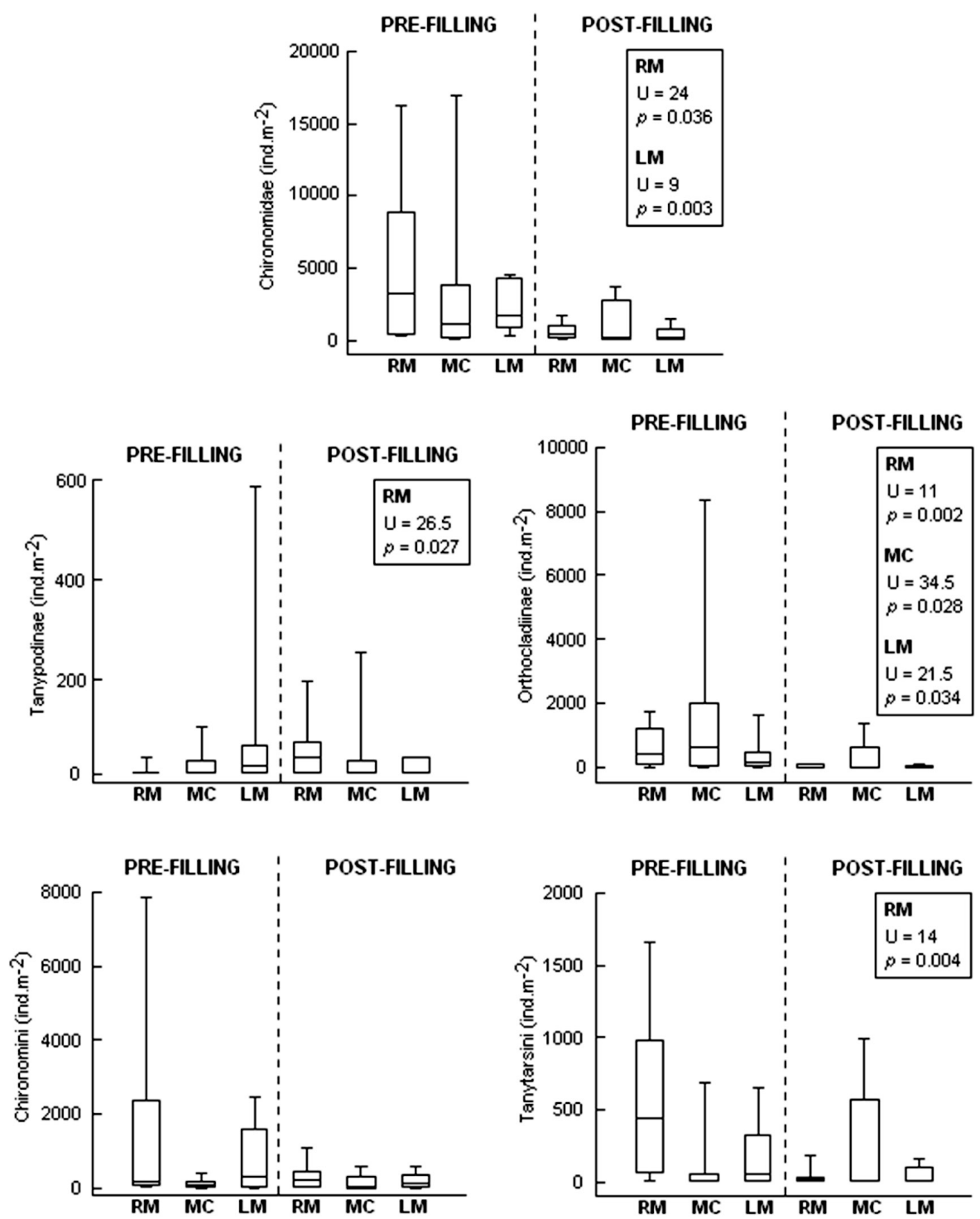

Figure 4. Median, percentiles, maximum, and minimum values of density of Chironomidae, Tanypodinae, Orthocladiinae, Chironomini, and Tanytarsini (ind. $\mathrm{m}^{-2}$ ) in the right margin (RM), main channel (MC), and left margin (LM) in the upper zone of Mogi-Guaçu reservoir (São Paulo State, Brazil) showing significant results for the U test. 

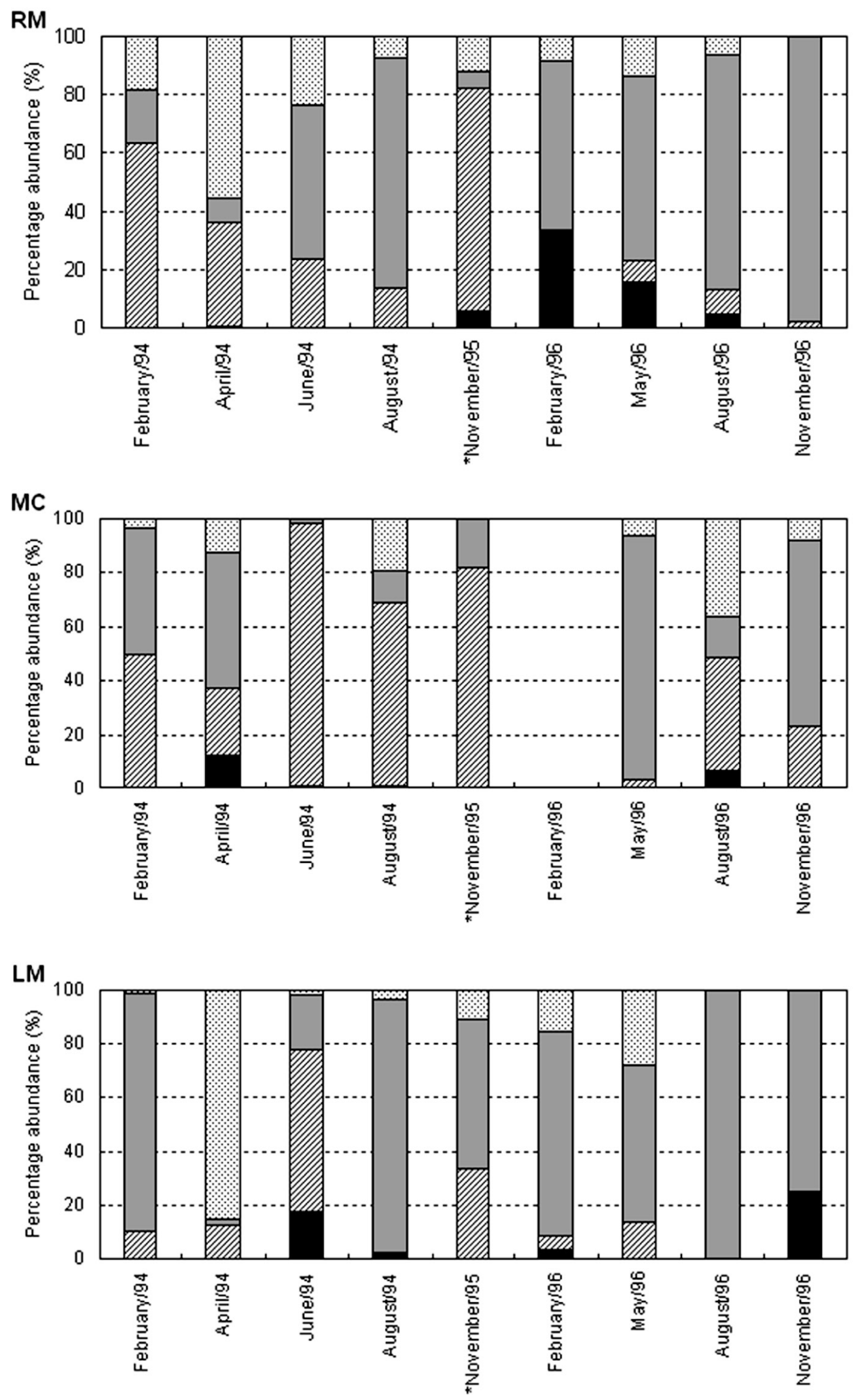

\begin{tabular}{|c|c|c|c|}
\hline - Tanypodinae & øOrthocladiinae & $\square$ Chironomini & QTanytarsini \\
\hline
\end{tabular}

Figure 5. Percentage abundance of groups of Chironomidae in the right margin (RM), main channel (MC), and left margin (LM) in the upper zone of Mogi-Guaçu reservoir (São Paulo State, Brazil). (*filling). 

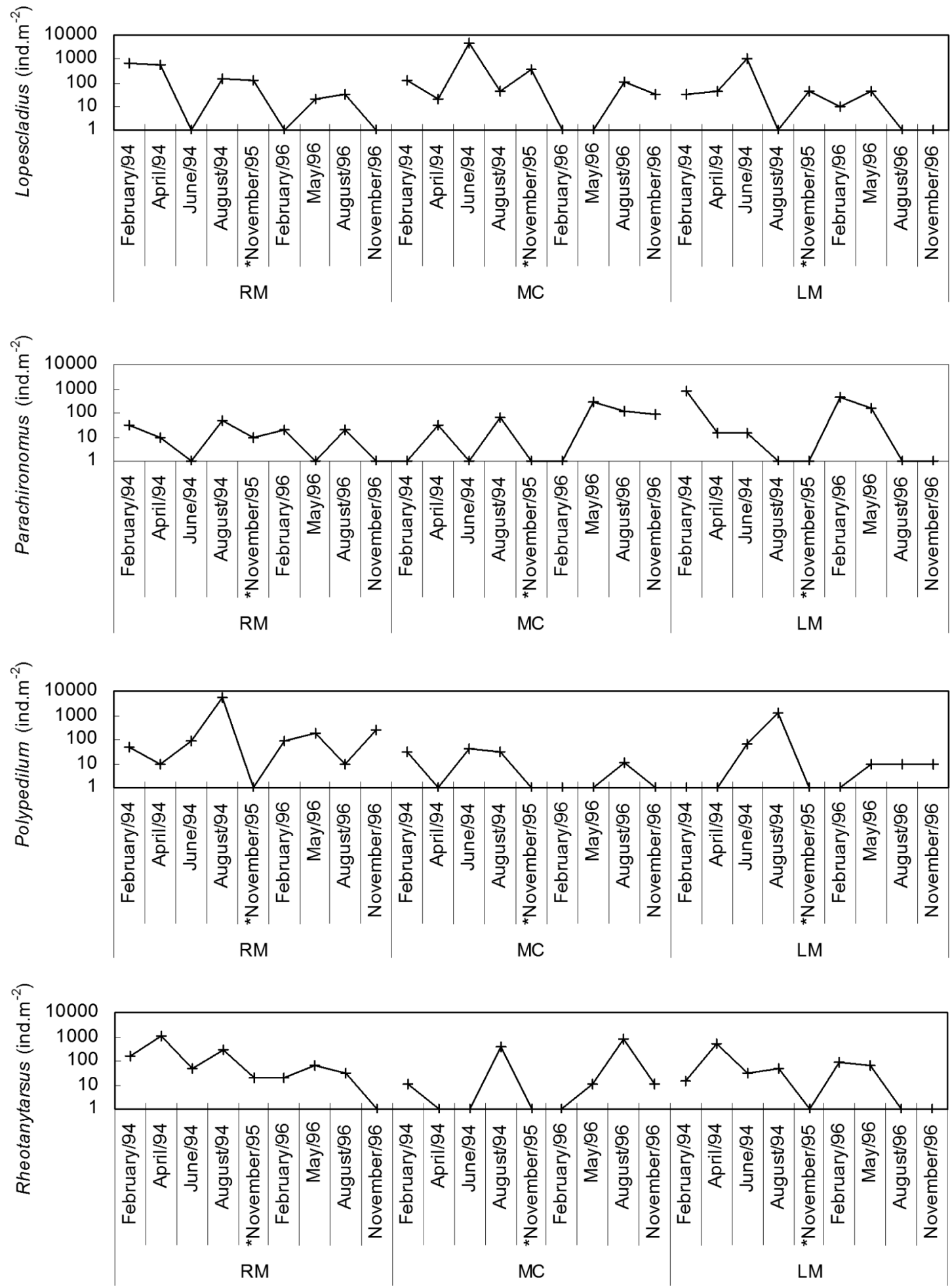

Figure 6. Density of the Chironomidae genera with highest Rosso's EVI values (ind. $\mathrm{m}^{-2}$ ) in the right margin (RM), main channel (MC), and left margin (LM) in the upper zone of Mogi-Guaçu reservoir (São Paulo State, Brazil) (see text for details). (*filling). 

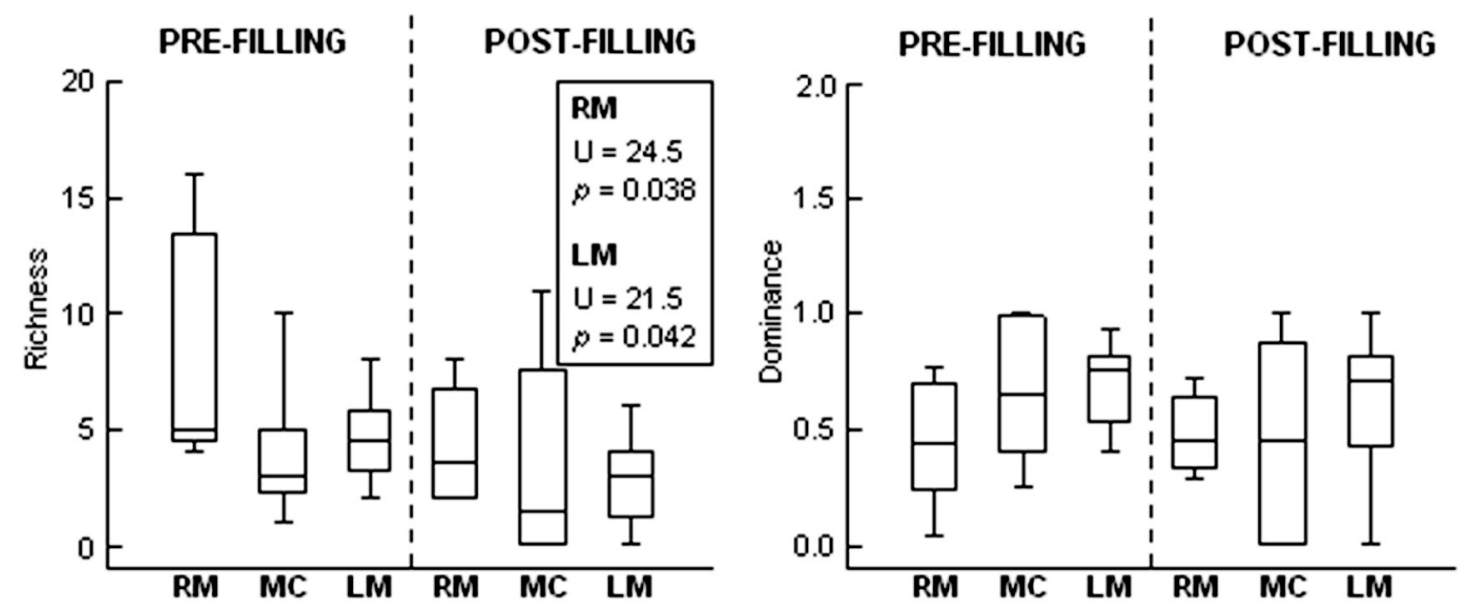

Figure 7. Median, percentiles, maximum, and minimum values of richness and dominance of Chironomidae genera in the right margin (RM), main channel (MC), and left margin (LM) in the upper zone of Mogi-Guaçu reservoir (São Paulo State, Brazil).

the substrate and probable higher availability of organic matter as food.

Decreases of Orthocladiinae and Tanytarsini in the post-filling phase were associated with the decline of current velocity because their principal components, Lopescladius and Rheotanytarsus, prefer primarily lotic conditions (Coffman and Ferrington Junior, 1996; Trivinho-Strixino, 2011).

The preference of Orthocladiinae and particularly Lopescladius for faster water was indirectly supported by the positive correlation between larvae density and surface flow. In Brazil, this genus was found in high densities in benthic communities at regulated sandy rivers (Rosin et al., 2009) and well-preserved lotic environments (e.g. Henriques-Oliveira et al., 2003a). The absence of records of this genus in a review about Chironomidae at lentic systems of São Paulo State (Roque et al., 2004) is evidence of its association with faster water. Moreover, the relationship between Lopescladius and sand substrate (e.g. Henriques-Oliveira et al., 2003a; Trivinho-Strixino, 2011) can explain its decrease in the post-filling phase as this fraction became less important.

The decrease of total Orthocladiinae and Tanytarsini in one or both of the margins can be also related to the change of substrate, which became finer. Substrate dominated by fine fractions, as seen in the margins after filling, are inappropriate for the settlement of many Chironomidae taxa (Hogg and Norris, 1991; Shimizu et al., 1995).

The dominance of Chironominae genera, mainly Polypedilum and Rheotanytarsus, in the post-filling phase could be due to a high availability of detritus. The relationship between these genera and detritus is well-established and observed by several authors such as Henriques-Oliveira et al. (2003b), Anjos and Takeda (2010), Trivinho-Strixino (2011), and Galizzi et al. (2012).

The densities of Polypedilum tended to be higher in margins and months with reduced surface current velocity in the pre-filling and post-filling phases. This genus occurs preferentially in lentic habitats, and, in general, larvae are shredders-herbivores and collectors-gatherers (Coffman and Ferrington Junior, 1996). Galizzi et al. (2012) and Henriques-Oliveira et al. (2003b) found a high percentage of amorphous detritus in the gut content of this genus. Therefore, in the upper zone of the Mogi-Guaçu reservoir, it was favored by the decline of current velocity and the expected higher sedimentation of organic matter in drier months.

The remaining terrestrial vegetation in the reservoir bottom could explain the increase of Parachironomus if we assume that vegetation has the same effect on sustaining habitat that submerged macrophytes, in which this genus is usually found, according Anjos and Takeda (2010). Changes in resources and conditions were certainly related to flow reduction and the flooding of riparian vegetation due to the river impoundment. Moreover, the increase in Chironomidae associated with the flooding and posterior degradation of terrestrial vegetation is a common event. It was observed, for example, in the Brazilian Paraibuna reservoir in the beginning of the rainy season, when larvae density increased substantially (Brandimarte and Shimizu, 1996).

The impact on the zoobenthic community in the first year after filling also occurred in a site downstream the Mogi-Guaçu dam, where total density and taxa richness decreased. Nevertheless, this tendency did not continue in the following two years, and the variation of both metrics remained in the same range as the pre-filling phase (Brandimarte et al., 2005). So, the impact on Chironomidae might not last in the upper zone of the reservoir. Moreover, as the impact varied according to the habitat analyzed, these results highlighted the need for a multi-habitat approach in environmental impact studies concerning the creation of new reservoirs. Therefore, it would be possible to make 
a more robust assessment of the damming impact on the aquatic biota.

Finally, our results sustain the use of Chironomidae as bioindicators because the damming impact was indicated by changes in the structure of this taxocenose. Genera with similar ecological traits (such as a preference for slower waters and detritivore habit) were less affected by the damming. On the other hand, there was a negative impact on the rheophilic genera. Although the analysis of traits did not become an objective of this paper, those results also could sustain the use of functional traits in the assessment of benthic communitie's responses to anthropogenic stressors as proposed by Poff et al. (2006).

\section{Acknowledgements}

The authors are grateful to the technicians of the São Paulo State Energy Company (CESP) for logistic support and to the Brazilian National Research Council (CNPq) for the Mauricio Anaya MS grant.

\section{References}

ANJOS, A.F. and TAKEDA, A.M., 2010. Acta Scientiarum. Biological Sciences Maringá, vol. 32, pp. 131-140.

BRANDIMARTE, A.L. and ANAYA, M., 1998. Flotation of bottom fauna using a solution of sodium chloride. Verhanlungen für Internationale Vereinigung für Theoretische und Angewandte Limnologie, vol. 26, pp. 2358-2359.

BRANDIMARTE, A.L. and SHIMIZU, G.Y., 1996. Temporal and spatial variations in littoral benthic communities of Paraibuna reservoir (São Paulo, Brazil). Tropical Ecology Varanas, vol. 37 , pp. 215-222.

BRANDIMARTE, A.L., ANAYA, M. and SHIMIZU, G.Y., 1997. Biomonitoramento para avaliação do impacto da construção do reservatório de aproveitamento múltiplo do rio Mogi-Guaçu (SP, Brasil). In: Anais do XII Simpósio Brasileiro de Recursos Hídricos, 1997, Vitória. Vitória: ABRH, pp. 297-304.

BRANDIMARTE, A.L., ANAYA, M. and SHIMIZU, G.Y., 1999. Comunidades de invertebrados bentônicos nas fases pré- e pósenchimento em reservatórios: um estudo de caso no reservatório de aproveitamento múltiplo do rio Mogi-Guaçu (SP). In: R. HENRY, ed. Ecologia de reservatórios: estrutura, função $e$ aspectos sociais. Botucatu: FAPESP/FUNDIBIO, pp. 377-407.

BRANDIMARTE, A.L., ANAYA, M. and SHIMIZU, G.Y., 2005. Downstream impact of Mogi-Guaçu river damming on the benthic invertebrates (São Paulo State, Brazil). Acta Limnologica Brasiliensia, vol. 17, pp. 27-36.

COFFMAN, W.P. and FERRINGTON JUNIOR, L.C., 1996. Chironomidae. In: R.W. MERRITT and K.W. CUMMINS, eds. An introduction to the aquatic insects of North America. 2nd ed. Dubuque: Kendall/Hunt. p. 635-754.

COMPANHIA ENERGÉTICA DO ESTADO DE SÃO PAULO - CESP, 1993. Aproveitamento múltiplo do Rio Mogi-Guaçu: PCH - Mogi-Guaçu: consolidação do projeto básico. São Paulo: Companhia Energética do Estado de São Paulo, vol. 2/2. 51 p. Estudo Ambiental.
CRANSTON, P.S., 1995. Introduction to Chironomidae. In: P.D. ARMITAGE, P.S. CRANSTON and L.C.V. PINDER, eds. The Chironomidae: biology and ecology of non-biting midges. London: Chapman \& Hall, pp. 1-7.

EPLER, J.H., 1992. Identification manual for the larval Chironomidae (Diptera) of Florida. Orlando: Department of Environmental Regulation.

GALIZZI, M.C., ZILLI, F. and MARCHESE, M., 2012. Diet and functional feeding groups of Chironomidae (Diptera) in the Middle Paraná River floodplain (Argentina). Iheringia: Série Zoologia, vol. 102, no. 2, pp. 117-121. http://dx.doi.org/10.1590/ S0073-47212012000200001.

GLOWACKI, L., GRZYBKOWSKA, M., DUKOWSKA, M. and PENCZAK, T., 2010. Effects of damming a large lowland river on chironomids and fish assessed with the (multiplicative partitioning of) true/hill biodiversity measure. River Research and Applications, vol. 27, no. 5, pp. 612-629. http://dx.doi. org/10.1002/rra.1380.

GREEN, R.H., 1979. Sampling design and statistical methods for environmental biologists. New York: John Wiley \& Sons.

GRZYBKOWSKA, M., KURZAWSKI, M. and DUKOWSKA, M.., 2012. Response of Chironomidae (Diptera) to impoundments in lowland streams. Fauna Norvegica, vol. 31, no. 0, pp. 25-33. http://dx.doi.org/10.5324/fn.v31i0.1379.

HAMMER, Ø., HARPER, D.A.T. and RYAN, P.D., 2001. PAST: Paleontological statistics software package for education and data analysis. Palaeontologia Electronica, vol. 4, no. 1, pp. 1-9.

HENRIQUES-OLIVEIRA, A.L., DORVILLÉ, L.F.M. and NESSIMIAN, J.L., 2003a. Distribution of Chironomidae larvae fauna (Insecta: Diptera) on different substrates in a stream at Floresta da Tijuca, RJ, Brazil. Acta Limnologica Brasiliensia, vol. 15 , pp. $69-84$

HENRIQUES-OLIVEIRA, A.L., NESSIMIAN, J.L. and DORVILLÉ, L.F.M., 2003b. Feeding habits of chironomid larvae (insecta: diptera) from a stream in the Floresta da Tijuca, Rio de Janeiro, Brazil. Brazilian Journal of Biology $=$ Revista Brasileira de Biologia, vol. 63, no. 2, pp. 269-281. http://dx.doi.org/10.1590/ S1519-69842003000200012. PMid:14509849.

HOGG, I.D. and NORRIS, R.H., 1991. Effects of runoff from land clearing and urban development on the distribution and abundance of macroinvertebrates in pool areas of a river. Australian Journal of Marine and Freshwater Research, vol. 42, no. 5, pp. 307-318. http://dx.doi.org/10.1071/MF9910507.

MAIER, M.H., BASILE-MARTINS, M.A., CIPÓLLI, M.N., VIEIRA, A.L. and CHIARA, E.G., 1978. Estudo limnológico de um trecho do Rio Moji-Guaçu. I. Características físicas. Boletim do Instituto de Pesca, vol. 5, no. 2, pp. 91-107.

NICHOLS, S., NORRIS, R., MAHER, W. and THOMS, M., 2006. Ecological effects of serial impoundment on the Cotter River, Australia. Hydrobiologia, vol. 572, no. 1, pp. 255-273. http://dx.doi.org/10.1007/s10750-005-0995-6.

OLIVER, D.R., 1971. Life history of Chironomidae. Annual Review of Entomology, vol. 16, no. 1, pp. 211-230. http://dx.doi. org/10.1146/annurev.en.16.010171.001235.

OLIVER, D.R., MCCLYMONT, D. and ROUSSEL, M.E., 1978. A key to some larvae of Chironomidae (Diptera) from the Mackenzie and Porcupine river watersheds. Winnipeg: Supply and Services Canada. 73 p. Fisheries \& Marine Service Technical Report, no. 791. 
PENCZAK, T., KRUK, A., GRZYBKOWSKA, A.M. and DUKOWSKA, M., 2006. Patterning of impoundment impact on chironomid assemblages and their environment with use of the self-organizing map (SOM). Acta Oecologica, vol. 30, no. 3, pp. 312-321. http://dx.doi.org/10.1016/j.actao.2006.05.007.

PETR, T., 1978. Man-made lakes: their ecological impacts. Archiv für Hydrobiologie, vol. 81, pp. 368-385.

PETTS, G.E., 1984. Impounded rivers: perspectives for ecological management. Chichester: Wiley. $326 \mathrm{p}$.

PINDER, L. and ROSSO, S., 1998. Classification and ordination of plant formations in the Pantanal of Brazil. Plant Ecology, vol. 136, no. 2, pp. 151-165. http://dx.doi.org/10.1023/A:1009796616824.

PINDER, L.C.V., 1986. Biology of freshwater Chironomidae. Annual Review of Entomology, vol. 31, no. 1, pp. 1-23. http:// dx.doi.org/10.1146/annurev.en.31.010186.000245.

POFF, N.L., OLDEN, J.D., VIEIRA, N.K.M., FINN, D.S., SIMMONS, M.P. and KONDRATIEFF, B.C., 2006. Functional trait niches of North American lotic insects: traits-based ecological applications in light of phylogenetic relationships. Journal of the North American Benthological Society, vol. 25, no. 4, pp. 730755. http://dx.doi.org/10.1899/0887-3593(2006)025[0730:FTN ONA]2.0.CO;2.

POWER, M.E., STOUT, R.J., CUSHING, C.E., HARPER, P.P., HAUER, F.R., MATTHEWS, W.J., MOYLE, P.B., STATZNER, B. and BADGEN, I.R.W., 1988. Biotic and abiotic controls in river and stream communities. Journal of the North American Benthological Society, vol. 7, no. 4, pp. 456-479. http://dx.doi. org/10.2307/1467301.

ROQUE, F.O., CORREIA, L.C.S., TRIVINHO-STRIXINO, S. and STRIXINO, G., 2004. A review of Chironomidae studies in lentic systems in the state of São Paulo, Brazil. Biota Neotropica, vol. 4, no. 2, pp. 1-19. http://dx.doi.org/10.1590/ S1676-06032004000200007.
ROSENBERG, D.M., DANKS, H.V. and LEHMKUHL, D.M., 1986. Importance of insects in environmental impact assessment. Environmental Management, vol. 10, no. 6, pp. 773-783. http:// dx.doi.org/10.1007/BF01867730.

ROSIN, G.C., OLIVEIRA-MANGAROTTI, D.P., TAKEDA, A.M. and BUTAKKA, C.M.M., 2009. Consequences of dam construction upstream of the Upper Paraná River floodplain (Brazil): a temporal analysis of the Chironomidae community over an eight-year period. Brazilian Journal of Biology $=$ Revista Brasileira de Biologia, vol. 69, no. 2, suppl., pp. 591-608. http:// dx.doi.org/10.1590/S1519-69842009000300014. PMid:19738966.

SHIMIZU, G.Y., CARVALHO, M.A.J., SENDACZ, S., LEMOS, M.M.G., GARCIA, E. and EYSINK, G.G.J., 1995. Lagoas de mineração de areia: impactos sobre os parâmetros ambientais e comunidades bióticas. In: Anais do $11^{\circ}$ Simpósio Brasileiro de Recursos Hídricos, 1995, Recife. Recife: Associação Brasileira de Recursos Hídricos, pp. 248-274.

TRIVINHO-STRIXINO, S. and STRIXINO, G., 1995. Larvas de Chironomidae (Diptera) do Estado de São Paulo: guia de identificação e diagnose dos gêneros. São Carlos: Programa de Pós-Graduação em Ecologia e Recursos Naturais, Universidade Federal de São Carlos. 229 p.

TRIVINHO-STRIXINO, S., 2011. Larvas de Chironomidae: guia de identificação. São Carlos: Laboratório de Entomologia, Departamento de Hidrobiologia, Universidade Federal de São Carlos. 371 p.

WETZEL, R.G. and LIKENS, G.E., 1991. Limnological analyses. 2nd ed. New York: Springer-Verlag. 391 p.

WIEDERHOLM, T., ed., 1983. Chironomidae of the Holartic region: keys and diagnoses. Part I - Larvae. Entomologica Scandinavia, suppl., pp. 33-110.

ZAR, J.H., 1999. Bioestatiscal analysis. 4th ed. Upper Saddle River: Prentice Hall. 